\title{
Blanka Serafin-Juszczak
}

Instytut Socjologii

Wydział Ekonomiczno-Socjologiczny

Uniwersytet Łódzki

\section{KIM JEST POLSKI NEET?}

\section{ISTOTA ZJAWISKA NEET}

Chcąc zweryfikować charakterystyki polskiego NEET, należy przede wszystkim ustalić, kim jest osoba określana jako NEET (not in employment, education or training). W literaturze przedmiotu kategoria jest definiowana niejednoznacznie. Zazwyczaj przy omawianiu tej kategorii autorzy (Furlong 2007: 105-106; Generation Jobless 2013) odnoszą się do wykluczenia młodych ludzi z rynku pracy oraz podają wysoką stopę bezrobocia młodzieży w Europie lub innym rejonie świata. $Z$ drugiej strony osób będących NEET nie można utożsamiać z bezrobotnymi - stopa bezrobocia i stopa NEET liczone są w odmienny sposób, a więc wartości mierzonych za pomocą tych dwóch wskaźników nie da się bezpośrednio ze sobą porównać (szerzej: Serafin-Juszczak 2014). Stopa bezrobocia odnosi się do odsetka osób młodych aktywnych zawodowo, które nie mogą znaleźć pracy. Innymi słowy, obejmuje jedynie ludzi zainteresowanych podjęciem zatrudnienia, ale niemogących go uzyskać. NEET-em natomiast jest osoba, która w ciągu ostatniego roku przynajmniej przez 6 miesięcy (łącznie) nie uczyła się, nie pracowała, nie podnosiła w żaden inny sposób swoich kwalifikacji (Eurofound 2012a: 77).

Niemniej refleksja nad kategorią bezrobocia jest nieunikniona. Analizy trendu ujawniają bowiem wyraźnie powiązanie wskaźnika NEET ze stopą bezrobocia młodych w wieku 15-24 lat i wskazują na znaczący wzrost obu wskaźników od kryzysu gospodarczego z 2008 roku (wykres 1).

Grupa NEET jest bardzo zróżnicowana - znajdują się w niej zarówno osoby szczególnie narażone na wykluczenie społeczne, jak i takie, które prawdopodobnie go nigdy nie doświadczą. Badania Eurofoundu ujawniły, że omawiana kategoria obejmuje przynajmniej pięć podgrup:

- bezrobotni (the conventionally unemployed) - grupa najliczniejsza, którą stanowią bezrobotni krótko- i długoterminowo; 
- niezdolni z różnych przyczyn do podjęcia aktywności w sferze pracy lub nauki (the unavailable) - młodzi chorzy, niepełnosprawni i opiekunowie ze zobowiązaniami rodzinnymi;

- niezaangażowani (the disengaged) - zniechęceni byli pracownicy lub bezrobotni, ale także młodzi prowadzący aspołeczny tryb życia;

- poszukujący/oczekujący (the opportunity-seekers) - młodzi aktywnie poszukujący pracy lub szkoleń, nie jakichkolwiek, lecz odpowiadających ich pozycji, umiejętnościom, aspiracjom zawodowym itp.;

- dobrowolni NEET-si (voluntary NEETs) - ta szczególna grupa obejmuje osoby zaangażowane w inne aktywności (sztukę, muzykę, podróże, samodoskonalenie się) (Eurofound 2012a: 24-25).

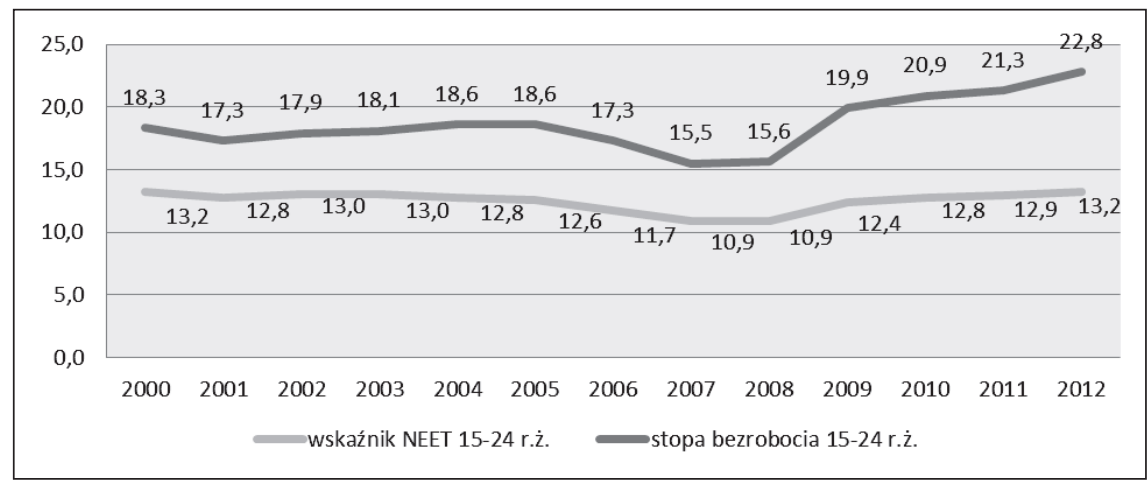

Wykres 1. Stopa bezrobocia ludzi młodych a stopa NEET w Unii Europejskiej w latach 2000-2012

Źródło: opracowanie własne na podstawie danych Eurostat (dostęp 20.01.2014).

Wprawdzie z różnych powodów, ale przedstawicieli wskazanych wyżej grup młodzieży łączy brak motywacji do kontynuowania formalnej edukacji lub zmiany kwalifikacji oraz brak zainteresowania aktywnością zawodową. Do grupy NEET należą osoby, które nie pracują z własnej woli, jak i tacy, którzy nie pracują, bo pomimo starań nie udaje im się znaleźć zatrudnienia lub pojawiają się przed nimi bariery w postaci niepełnosprawności czy konieczności opieki nad niesamodzielnymi członkami rodziny (Eurofound 2012a: 22).

Sporna jest także kwestia wieku młodego człowieka, w którym można go zaliczyć (lub nie) do NEET-ów. Unia Europejska jako podstawową przyjęła kategorię 15-24 lat, choć stosowane są także bardziej szczegółowe klasyfikacje ze względu na wiek, m.in. 16-18 lat, 18-24 itd. Istnieją też rozszerzone statystyki odnoszące się do młodych ludzi w wieku 15-29 lat, a nawet 25-34 (Furlong 2007: 109). Co więcej, to właśnie w najstarszej grupie wiekowej - dla Europy są to dane 
uwzględniające osoby między 25-29 rokiem życia - wskaźnik osiąga ekstremalne wartości, dotykając osób bez zatrudnienia, ale dobrze wyedukowanych, często $\mathrm{z}$ wyższym wykształceniem, którzy nie widzą sensu w dalszej nauce lub zmianie zawodu.

Choć głównym zagadnieniem podjętym w niniejszym artykule jest charakterystyka zjawiska w Polsce na tle Unii Europejskiej, należy zauważyć, że problem NEET nie jest tylko europejski. Pomiędzy poszczególnymi kontynentami i rejonami występują znaczne różnice w skali NEET. Szacunki OECD i Banku Światowego wskazują, że poza sferą pracy i edukacji pozostaje prawie jedna czwarta młodzieży świata (Generation jobless, 2013).

\section{CHARAKTERYSTYKA ZJAWISKA W POLSCE}

W Polsce brak jest szeroko zakrojonych studiów dotyczących grupy NEET. Większość prac dotyczy osób bezrobotnych zarówno z punktu widzenia socjologii, psychologii, jak i ekonomii (Budnikowski 2009; Ratajczak 2002) lub poświęcona jest badaniom losów młodzieży doświadczonej przez biedę, wychowanie w rodzinie dysfunkcyjnej, chorobę czy też niepełnosprawność, uwikłanej w przestępczość, wskutek czego przedwcześnie odpływa z edukacji (Grotowska-Leder 2006; Warzywoda-Kruszyńska 2012). Kategoria NEET od kilku edycji pojawia się jednak w Diagnozie Społecznej. Z badań tych wynika, że bierni zawodowo i edukacyjnie w wieku 15-24 stanowili w latach 2000-2005 około 13\%. Ten stabilny poziom w kolejnych latach zaczął się zmniejszać (do 9\%), lecz w 2013 roku osiągnął pozom 10,2\% (Czapiński, Panek 2013: 95-96).

$\mathrm{Z}$ danych wypływa wniosek że odsetek młodych osób pozostających poza sferą edukacji i zatrudnienia praktycznie nie zmienia się, niezależnie od tego czy rozpatruje się Unię Europejską po ostatnim rozszerzeniu o Chorwację, UE dwudziestu siedmiu państw czy wyłącznie kraje strefy euro, ale także tak zwaną ,starą Unię" składającą się z piętnastu państw. Różnice uwidaczniają się nie tyle między państwami, co między poszczególnymi regionami.

Podstawowa charakterystyka z Diagnozy spotecznej jest dość spójna z danymi dostępnymi w bazach danych Eurostat. Polska w zestawieniu państw UE według wskaźnika NEET dla młodzieży 15-24 znajdowała się nieznacznie poniżej średniej unijnej - 11,8\%. Biorąc pod uwagę rozszerzony przedział wiekowy 15-29, średnia unijna stopy NEET za 2012 rok kształtowała się na poziomie aż 15,9\% (linia pozioma na wykresie 2), dla naszego kraju wartość ta była bardzo zbliżona i wyniosła $15,7 \%$. 


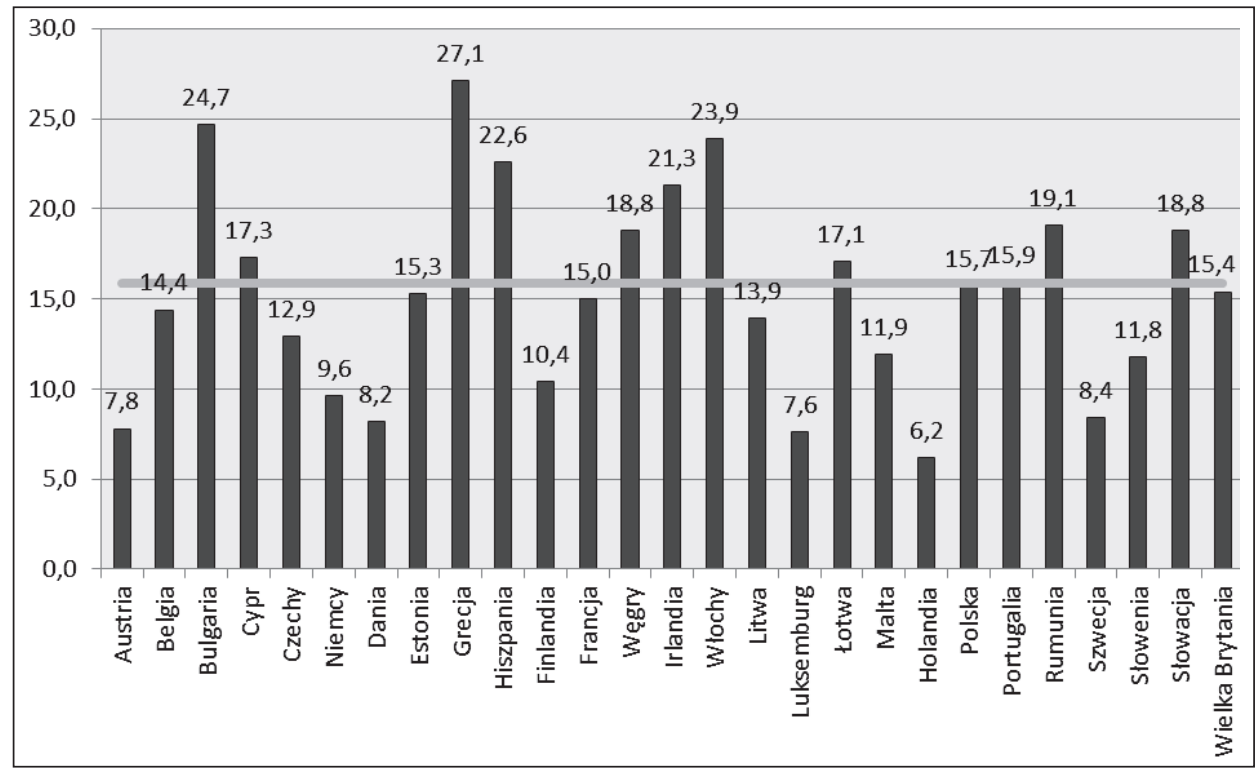

Wykres 2. Wskaźnik NEET w wieku 15-29 w UE w 2012 roku według krajów

Źródło: opracowanie własne na podstawie danych Eurostat (dostęp 20.01.2014).

Ryzyko bycia NEET-em w UE ogółem jest większe dla kobiet niż dla mężczyzn. Nie w każdym państwie członkowskim występuje feminizacja zjawiska, czyli odsetek NEET jest większy wśród kobiet. Są natomiast kraje -Irlandia, Hiszpania, Litwa, Portugalia, Słowenia, Słowacja, Cypr, Luxemburg i Francja - w których większy odsetek osób o statusie NEET jest wśród młodych mężczyzn niż wśród młodych kobiet, co oznacza maskulinizację tego zjawiska. Natomiast wyrównane proporcje w tym zakresie cechują takie kraje jak: Austria, Belgia, Bułgaria, Dania, Finlandia, Szwecja i Włochy.

W Polsce wskaźnik NEET według płci kształtuje się poniżej średniej unijnej - wynosząc odpowiednio dla mężczyzn i kobiet $11,5 \%$ i $12,2 \%$, ale nasze państwo od wielu lat cechuje feminizacja zjawiska. Największą dysproporcję na niekorzyść kobiet odnotowano w Polsce w latach 2007-2008 (różnica wynosiła odpowiednio 2,6 i 3,5 punktów procentowych), ale od tego czasu zaznaczyła się wyraźna tendencja do jej spadku - dysproporcja wyniosła już jedynie 0,7 punkta procentowego w roku 2012 (wykres 3).

Porównując wyniki najnowszej Diagnozy społecznej widzimy wskazuje, że odsetek NEET wśród młodych polskich kobiet spadał aż do 2011 roku, dopiero w 2013 roku zanotowano jego wzrost o 1,8 punktu procentowego. U mężczyzn wyraźniejszy spadek nastąpił po 2005 roku i, podobnie jak w przypadku kobiet, zanotowano jego tendencję wzrostową w 2013 roku. Według autorów „różnice 
w dynamice zmian wskaźnika NEET według płci w całym analizowanym okresie związane mogą być z większą aktywnością edukacyjną kobiet, szczególnie w latach 2000-2005. Analizowany wskaźnik 'bierności ogólnej' jest na ogół mniejszy dla kobiet niż mężczyzn, niższa aktywność zawodowa kobiet w tej grupie wieku jest rekompensowana ich wyższą aktywnością edukacyjną w porównaniu z mężczyznami” (Czapiński, Panek 2013: 96).

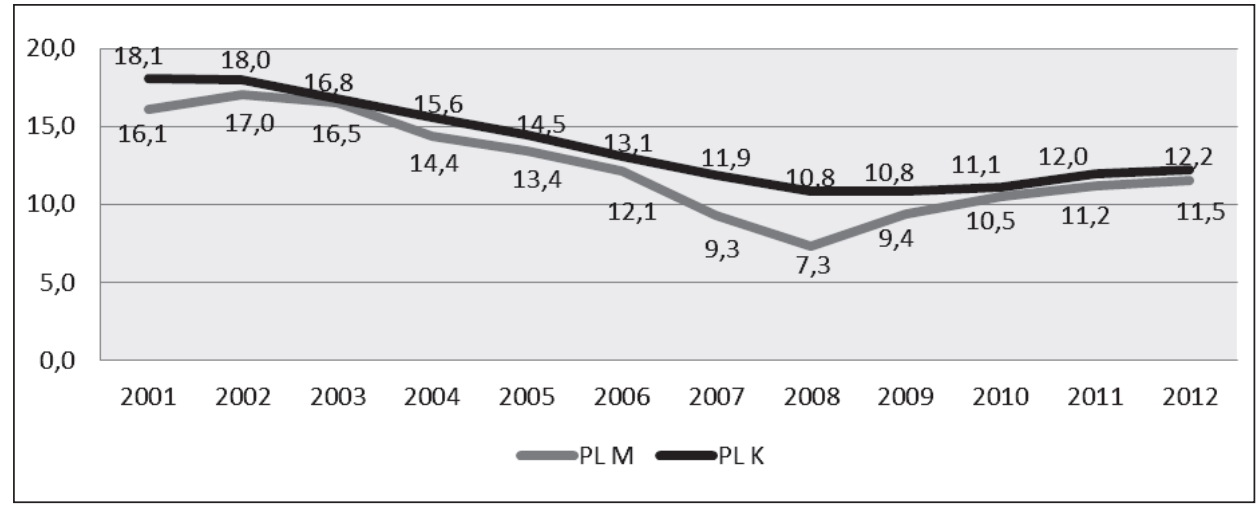

Wykres 3. Wskaźnik NEET w Polsce według płci dla młodzieży pomiędzy 15-24 rokiem życia

Źródło: opracowanie własne na podstawie danych Eurostat (dostęp 01.02.2014).

Analizując dane według kryterium miejsca zamieszkania obserwujemy, że nadal większy jest udział NEET wśród młodzieży żyjącej na wsi (wykres 4). Na wykresie przedstawiono, jak do 2009 roku zmniejszała się dysproporcja między środowiskami miejskimi a wiejskimi pod kątem wielkości wskaźnika NEET, lecz ostatnie dwie edycje badania panelowego, przeprowadzone w latach 2011 i 2013, dostarczyły danych wskazujących na zwrot tego trendu. Obecnie znów zauważalna jest uprzywilejowana pozycja młodzieży zamieszkującej miasta.

Badania Europejskiej Fundacji na Rzecz Poprawy Warunków Życia i Pracy (Eurofound) wykazały, że w poszczególnych państwach członkowskich UE są różne wzory kształtowania się NEET:

1. Niski wskaźnik NEET: nieaktywni zawodowo, z doświadczeniem zawodowym, nisko wykwalifikowani (Austria, Dania, Finlandia, Niemcy, Luksemburg, Szwecja, Wielka Brytania).

2. Wysoki wskaźnik NEET: kobiety, nieaktywni zawodowo, bez doświadczenia, wysoko wykwalifikowani, ,zniechęceni pracownicy” (Grecja, Polska, Słowacja, Węgry, Bułgaria, Włochy, Rumunia).

3. Wskaźnik poniżej średniej europejskiej: bezrobotni, z doświadczeniem zawodowym, średnio wykwalifikowani (Estonia, Litwa, Łotwa, Irlandia, Hiszpania, Portugalia). 
4. Wysoki wskaźnik NEET: mężczyźni, bezrobotni, bez doświadczenia, wysoko wykwalifikowani, „zniechęceni pracownicy” (Belgia, Cypr, Czechy, Francja, Słowenia).

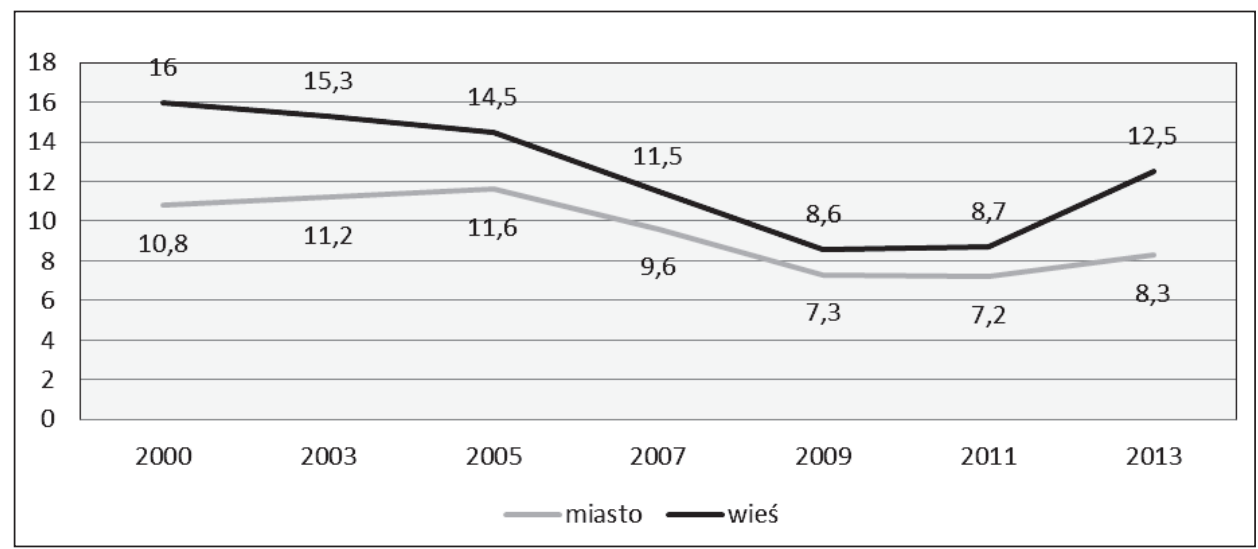

Wykres 4. Stopa NEET w wieku 15-24 w Polsce według miejsca zamieszkania w latach 2000-2013

Źródło: opracowanie własne na podstawie Czapiński, Panek 2013.

W Polsce występuje drugi wzór kształtowania się wskaźnika NEET, choć nie jest państwem najbardziej charakterystycznym dla tego klastra. Obok Polski i Czech wzór te występuje w krajach o wysokim odsetku NEET-ów, którzy borykają się z barierami strukturalnymi w przejściu młodzieży z edukacji na rynek pracy. Status NEET w Polsce nie jest kwestią wyboru, a w kategorii znacznie większy jest udział kobiet, osób nieaktywnych zawodowo i bez doświadczenia w pracy (lub z doświadczeniem zawodowym poniżej unijnej średniej), choć w wielu wypadkach są to jednostki wysoko wykwalifikowane.

Uogólniając można zauważyć, że wśród Polaków częściej niż przeciętnie w Europie osoby będące NEET są nimi z przymusu, a rzeszę młodych ludzi stanowią tzw. byli zniechęceni pracownicy, co ma poważne negatywne skutki dla jednostki, społeczeństwa i gospodarki. W 2011 roku same straty ekonomiczne ${ }^{1}$ spowodowane wyłączeniem młodych ludzi z rynku pracy wyniosły w UE, według

${ }^{1}$ Oprócz kosztów ekonomicznych wskaźnik NEET pociąga za sobą koszty dla jednostki i społeczeństwa. Wykluczenie z pracy i z edukacji ma szereg konsekwencji psychologicznych: stres, wybuchy agresji, stany depresyjne, sprzyja nadużywaniu substancji psychoaktywnych i innym uzależnieniom, agresji. Ma ponadto wpływ na funkcjonowanie rodziny, sprzyja nasileniu przemocy wśród bliskich i procesom dezintegracyjnym, których przejawem są m.in. rozwody. Rodzi bierność i niesamodzielność przedstawicieli młodego pokolenia, odracza moment ich usamodzielnienia ekonomicznego i zakładania rodzin, prokreacji (European Commission 2012: 7). 
ostrożnych szacunków, 153 miliardów euro, co odpowiada 1,2\% europejskiego PKB. Niektóre państwa płacą szczególnie wysoką cenę za młodzież pozostającą NEET - generowane przez nią koszty odpowiadają 2\% lub więcej ich PKB. Tak jest w Polsce $(2,04 \% \mathrm{PKB})$, a porównywalny lub gorszy wpływ na budżet państwa mają NEETs w Bułgarii, Grecji, Irlandii, Włoszech oraz na Łotwie, Cyprze i Węgrzech. Dla porównania, w krajach takich jak Luksemburg, Szwecja, Niemcy i Dania nie przekracza 0,23-0,6\% (Eurofound 2012a: 79-80).

Koszty generowane przez NEET obejmują m.in. zasiłki dla osób bezrobotnych. Według danych Eurostatu wśród ogółu młodych członków Wspólnoty Europejskiej na początku 2012 roku stopa bezrobocia wzrosła do blisko 23\%, a w Polsce sięgnęła ona 26,5\%. Rozkład zatrudnienia młodych osób w poszczególnych sektorach stanowi podstawę wyjaśnienia, dlaczego zostali oni tak bardzo dotknięci przez kryzys ekonomiczny. Większość młodych ludzi w Europie pracuje w handlu oraz produkcji, a wielu innych znajduje zatrudnienie w hotelarstwie i gastronomii, usługach zdrowotnych i opiece społecznej oraz budownictwie. W 2011 roku (w porównaniu do 2008) liczba osób zatrudnionych w branżach handlowej i produkcyjnej spadła z 3,6 do 2,7 miliona, podczas gdy zatrudnionych w budownictwie z 2,2 do 1,6 miliona (Eurostat 2013).

Warto podkreślić, że od 2008 roku nastąpił spadek zatrudnienia młodzieży niemal we wszystkich sektorach i branżach gospodarki, nawet - co jest szczególnie zaskakujące - w informatyce i telekomunikacji. Jedynymi wyjątkami są zdrowie i opieka społeczna, a także edukacja, gdzie zanotowano niemalże 3-procentowy wzrost zatrudnienia. Oczywiście dane szczegółowe dla Unii Europejskiej ukazują niejednoznaczność tych trendów dla poszczególnych państw. Na przykład w Polsce, podobnie jak w Niemczech lub Szwecji w ciągu ostatnich lat zanotowano zwiększenie zatrudnienia młodych osób w sektorze budownictwa - w naszym państwie spowodowane było to m.in. pracami związanymi z Euro 2012 oraz koniecznością wywiązania się z inwestycji współfinansowanych z funduszy europejskich w okresie programowania 2007-2014. Znaczące spadki zarówno w produkcji przemysłowej, jak i budownictwie miały natomiast miejsce w państwach takich jak Irlandia czy Hiszpania (Eurofound 2012a: 20).

Kolejnym wyjaśnieniem trudnej sytuacji młodzieży na rynku pracy jest forma jej zatrudnienia, czyli umowy cywilnoprawne oraz umowy na czas określony. Należy podkreślić, że wśród 19,4 mln zatrudnionej młodzieży jedynie około 4\% należało do osób samozatrudnionych, a ponad pół miliona pracowało w przedsiębiorstwach prowadzonych przez ich krewnych. Polska, wraz z Rumunią i Słowenią, w 2011 roku należała do państw, gdzie młodzież relatywnie często znajdowała pracę w firmach rodzinnych. Nie jest zaskoczeniem, że po spadku w 2008 roku, udział młodzieży pracującej na czas określony wzrósł w czasie kryzysu gospodarczego, osiągając $42 \% \mathrm{w}$ roku 2011. Tymczasowe zatrudnienie zostało zmniejszone jedynie przez brak odnowienia umów z pracownikami, którzy 
nie byli potrzebni w czasie gorszej koniunktury. Nawet gdy gospodarka zaczyna się stabilizować, czasowe umowy są postrzegane przez pracodawców jako dobra alternatywa $\mathrm{w}$ niepewnych czasach, zmniejszająca koszty i poprawiająca elastyczność zatrudnienia w ich firmach (European Commission 2012: 29).

Polska wraz ze Słowenią i Hiszpanią przoduje wśród państw Wspólnoty, w których młodzi ludzie pracują na umowach czasowych. Ponad $60 \% \mathrm{z}$ nich w 2011 roku miało podpisaną umowę na czas określony. Analizy zawarte w Diagnozie Społecznej 2013 potwierdzają, że stosowanie mniej stabilnych form zatrudnienia jest $\mathrm{w}$ Polsce skorelowane $\mathrm{z}$ wiekiem. Im młodszy pracownik, tym częściej jest zatrudniony na czas określony, a także częściej deklaruje intensywne poszukiwanie innej pracy. Wśród młodzieży do 24 roku życia jedynie około jednej piątej zatrudnionych zaproponowano umowę o pracę na czas nieokreślony. Wraz z wiekiem następuje zdecydowana stabilizacja warunków zatrudnienia - w grupie osób w wieku 25-34 lata odsetek zatrudnionych na czas nieokreślony wynosi 55\% dla mężczyzn i 52\% dla kobiet. W kolejnych grupach wiekowych udział ten stabilizuje się dla mężczyzn i rośnie dla kobiet, a im wyższy wiek osoby badanej, tym mniejsze prawdopodobieństwo, że będzie ona pracowała na umowę czasową. Co interesujące, w przypadku polskich mężczyzn wraz z wiekiem rośnie także udział osób samozatrudnionych, poza rolnictwem indywidualnym (Czapiński, Panek 2013: 135).

Status NEET dotyczy też młodzieży, która zbyt wcześnie ukończyła karierę szkolną i przestała się uczyć. Jednym ze sposobów przeciwdziałania przedwczesnemu wypadaniu z edukacji (early school leaving) jest zwiększanie zakresu obowiązkowej edukacji wśród państw europejskich oraz zadbanie, by uczniowie nie opuszczali szkoły bez uzyskania podstawowego zestawu umiejętności i kompetencji. Niektóre z krajów zdecydowały się na podniesienie wieku kształcenia obowiązkowego (np. Włochy, Anglia i Portugalia), podczas gdy inne zastosowały obniżony próg wieku, w którym dzieci muszą rozpocząć naukę.

Polska należy do państw, w których obowiązek szkolny trwa do ukończenia gimnazjum, a do 18 roku życia istnieje jednak obowiązek nauki. W praktyce oznacza to, że nauka po ukończeniu gimnazjum w wieku 16 lat (bez powtarzania klasy), musi być kontynuowana w szkole ponadgimnazjalnej, lub w jednej z innych form kształcenia określonych przez ustawodawcę, przynajmniej do uzyskania - mówiąc w pewnym uproszczeniu - pełnoletności (art. 16 ust. 5a ustawy z dnia 7 września 1991 r. o systemie oświaty, Dz. U. z 2004 r., nr 256, poz. 2572, z późn. zm.). Oznacza to, że wśród polskiej młodzieży do 18 roku życia, zgodnie z przepisami prawa, zjawisko NEET nie powinno występować. Oczywiście tak nie jest, choć odsetek najmłodszych NEET-ów, przynajmniej w porównaniu do starszych podgrup jest marginalny. Dodatkowo udział NEET wśród chłopców i dziewcząt do 18 roku życia z roku na rok stopniowo się zmniejsza, co można zaobserwować nie tylko w Polsce, ale w całej Unii (wykres 5). Przeciwny trend występuje natomiast wśród pozostałych grup wiekowych. 


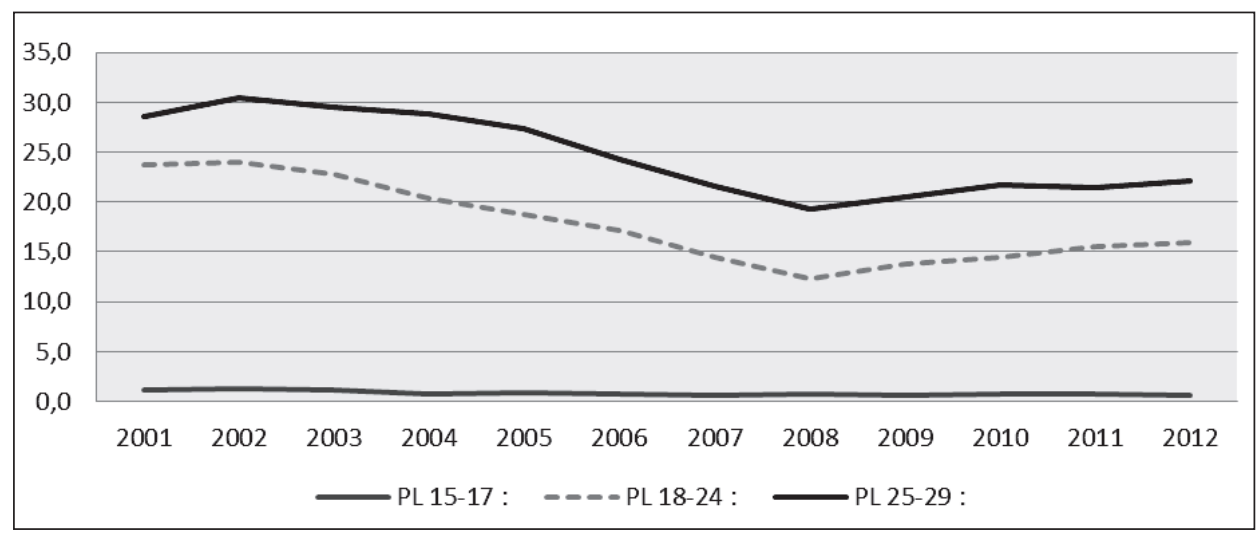

Wykres 5.Wskaźnik NEET w Polsce w wybranych grupach wiekowych w latach 2001-2012

Źródło: opracowanie własne na podstawie danych Eurostat (dostęp 01.02.2014).

Najmłodszych NEET-ów jest w Polsce zdecydowanie mniej niż w innych europejskich państwach (w 2012 roku przeciętny odsetek dla UE wyniósł 3,3\%, a dla wielu krajów było to powyżej 5 nawet do 7,6\% w Irlandii). Wobec powyższych danych zasadne wydaje, by w Polsce szczególny nacisk położyć na zbadanie kategorii NEET-ów powyżej 18 roku życia.

Analiza najnowszych danych statystycznych dotyczących udziału NEET-ów wśród osób w wieku 18-24 w Polsce według województw, pozwoliła także na zilustrowanie rozkładu wskaźnika NEET w poszczególnych województwach (wykres 6):

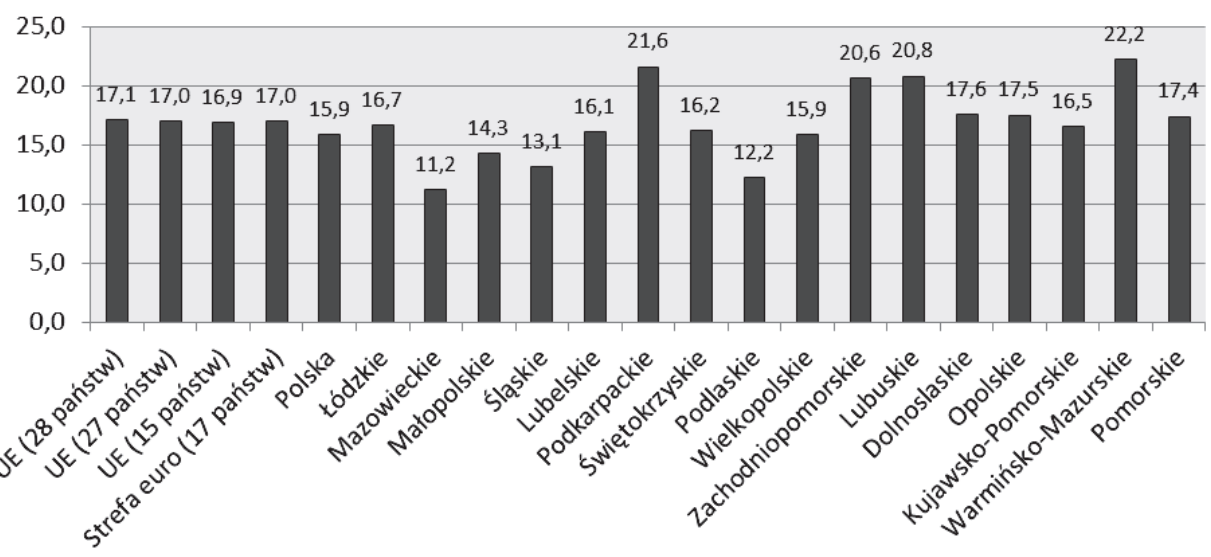

Wykres 6. Wskaźnik NEET dla osób w wieku 18-24 w Polsce według województw w 2012 roku Źródło: opracowanie własne na podstawie danych Eurostat (dostęp 01.02.2014). 
Nie jest zaskoczeniem, że najniższy wskaźnik obejmuje województwo mazowieckie, choć nadal ponad $11 \%$ zamieszkującej w nim młodzieży powyżej 18 roku życia nie uczy się ani nie pracuje. Województwo łódzkie z wartością $16,7 \%$ znajduje się w tym zestawieniu nieznacznie poniżej średniej unijnej, ale powyżej średniej dla całej Polski. Powyżej 20\% młodych ludzi poza sferą pracy i edukacji pozostaje w województwach: podkarpackim, zachodniopomorskim i lubuskim. Najwyższy odsetek zaobserwowano w regionie warmińsko-mazurskim - aż $22,2 \%$.

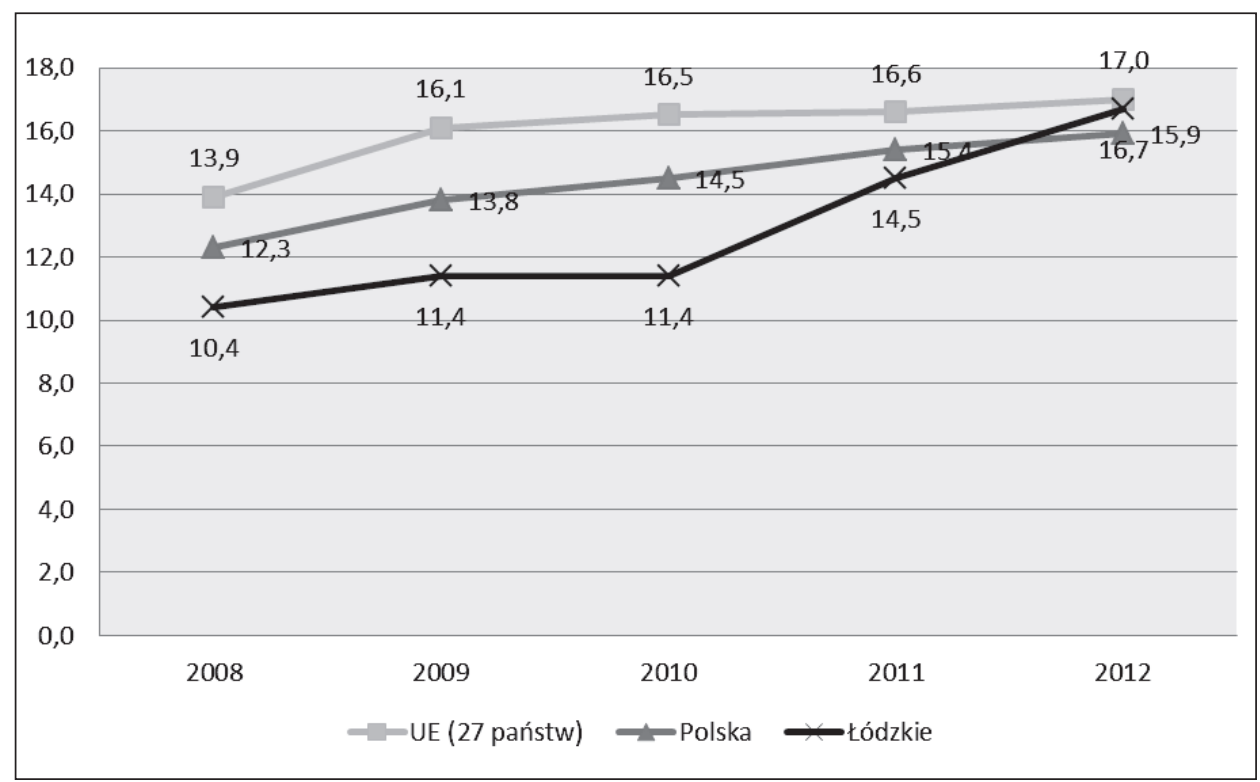

Wykres 7. Dynamika wskaźnika NEET 18-24 w latach 2008-2012 w województwie łódzkim, w Polsce i w UE

Źródło: opracowanie własne na podstawie danych Eurostat (dostęp 01.02.2014).

Na wykresie 7 zaprezentowano, jak zmieniał się wskaźnik dla Polski i województwa łódzkiego na tle UE na przestrzeni ostatnich kilku lat (od kryzysu gospodarczego z 2008 roku). Warto zauważyć, że wśród osób między 18 a 24 rokiem życia w 2012 roku wystąpiły niewielkie różnice w odsetku NEET dla całej Unii, dla Polski i dla województwa łódzkiego. Niepokojące jest jednak wyraźne zwiększenie dynamiki wzrostu wskaźnika dla województwa łódzkiego. O ile do 2010 roku w województwo znajdowało się wyraźnie poniżej średniej dla UE i Polski, o tyle dwa lata później jest już na poziomie UE i nieco powyżej uśrednionej wartości wskaźnika dla naszego kraju. 


\section{PRZEZWYCIĘŻANIE ZJAWISKA NEET W POLSCE}

Polska została przez Komisję Europejską sklasyfikowana wśród państw, w których główną przyczyną przedwczesnego wypadania młodzieży z rynku edukacji jest ubóstwo. Wsparcie najmłodszych z najbiedniejszych rodzin prowadzone jest w formie dotowanych książek do nauki, darmowych posiłków, zasiłków i stypendiów, które oprócz Polski występują także we Włoszech, Portugalii i Słowacji. Dobrym posunięciem wydaje się być zwiększenie roli kształcenia zawodowego w Polsce, nacisk na umożliwienie młodym ludziom zdobywania umiejętności i cech, które są uznawane przez pracodawców za ważne oraz są poszukiwane na rynku pracy (Eurofound 2012b: 20-22).

Kto w Polsce korzysta $\mathrm{z}$ usług edukacyjnych według statusu rynku pracy? Powyżej 18 roku życia w 2013 roku około 63,5\% stanowili bierni zawodowo (dla porównania było to $60 \%$ w latach 2011,2009 i 2007). Spośród nich prawie $87 \%$ to grupa młodzieży do 24 roku życia znajdująca się w systemie edukacji szkolnej (zanotowano nieznaczny spadek w porównaniu do ubiegłorocznych edycji Diagnozy społecznej - 89\% w 2011, 91\% w 2009, 95\% w 2007).

Należy zauważyć, że wśród aktywnych zawodowo, którzy podejmowali naukę (powyżej 18 roku życia, a więc nieobjętych już obowiązkiem szkolnym) bezrobotni stanowili 13,2\% (dla porównania 13,6\% w 2011, 8,5\%. w 2009 i 14\% w 2007). Wydaje się, że jest to odsetek niewielki, przynajmniej z dwóch powodów. Po pierwsze, do tych osób, jako szczególnie narażonych na wykluczenie społeczne, skierowane były liczne programy umożliwiające podniesienie kwalifikacji lub zmianę zawodu, najczęściej bezpłatne, finansowane w ramach Programu Operacyjnego Kapitał Ludzki. Drugim argumentem jest to, że osobom bezrobotnym szczególnie powinno zależeć na podniesieniu kwalifikacji, umożliwiających znalezienie pracy - a przypomnijmy, że są to osoby określające się jako (przynajmniej teoretycznie) gotowe do podjęcia pracy w ciągu najbliższych dni, bez zobowiązań uniemożliwiających jakąkolwiek aktywność w sferze nauki lub pracy. Dodatkowo w procesie doszkalania się wśród osób w wieku powyżej 24 lat uczestniczą głównie pracujący, którzy przeciętnie mają już wyższe kwalifikacje niż osoby bezrobotne czy bierne zawodowo. Na gruncie polskim rodzi to swoistą bipolarność - z jednej strony wśród młodzieży mamy osoby pracujące, uczące się, a często wykazujące sferę tych dwóch aktywności naraz, z drugiej bezrobotnych, którzy niechętnie podnoszą swoje kwalifikacje.

Aktywność edukacyjną częściej wykazują kobiety - powyżej 18 roku życia uczące się kobiety stanowily $58,3 \%$ bezrobotnych oraz 58,5\% pracujących (w 2011 odpowiednio 65,5\% i 58,2\%, w 2009 - 54,5\% i 53,7\%.). Osoby aktywne zawodowo i edukacyjnie preferowały usługi świadczone w trybie szkolnym (wybierało je 70,2\% pracujących oraz $81,7 \%$ bezrobotnych). W ostatnich latach zauważalnie wzrosło jednak znaczenie usług edukacyjnych w trybie pozaszkolnym, szczególnie w przypadku osób pracujących (Czapiński, Panek 2013: 95). 


\section{PODSUMOWANIE}

Jak dotąd nie powstało w kompleksowe opracowanie dotyczące polskich NEET-ów, czyli osób bezrobotnych lub biernych zawodowo, z wyłączeniem tych, którzy podejmują naukę dla pozyskania odpowiedniego poziomu wykształcenia lub nabycia kwalifikacji. Brak jest badań ukazujących, które z wyodrębnionych podgrup NEET są w Polsce najliczniejsze i jak bardzo młodzież ta narażona jest na wykluczenie społeczne - a jest bardzo prawdopodobne, że inne przyczyny i skutki bycia NEET-em dotyczą osób, które przedwcześnie zakończyły edukację, doświadczają barier związanych z niepełnosprawnością własną lub niesamodzielnością członka rodziny, inne zaś absolwentom studiów wyższych, którzy nie znajdują pracy stosownej do ich wykształcenia. Istnienie tak dużej liczby NEET-ów to także koszty, zarówno te wyrażone w euro, jak i nieprzeliczalne na żadną walutę, związane z niewykorzystywanym potencjałem młodych ludzi - potencjałem rozumianym zarówno jako tu i teraz, służącym wytwarzaniu PKB, ale też będącym „polisą na przyszłość” i polegającym na wykorzystaniu największej chłonności do nauki, poszukiwaniu zainteresowań, wyborze satysfakcjonującej i pozwalającej na usamodzielnienie się profesji.

Oprócz danych demograficznych, dotyczących płci, wykształcenia, miejsca zamieszkania interesujące oraz zasadne byłoby zbadanie, dlaczego niektórzy radzą sobie mimo niesprzyjającej koniunktury, jaką mają motywację do pracy lub nauki, a co stoi za jej brakiem. Innymi słowy co odróżnia NEET od EET (in education employment or training) oraz jakie są czynniki ryzyka stawania się NEET, a następnie pozostawania poza zatrudnieniem i edukacją. Warto ponadto rozważyć jakie są rzeczywiste potrzeby takich młodych osób, jakiej ewentualnej pomocy wymagają ze strony państwa i jak na tym tle kształtuje się efektywność dotychczasowej polityki Unii Europejskiej.

Polska na równi z innymi państwami stoi w obliczu wyboru strategii zaradczych wobec młodzieży i jej trudnego położenia na współczesnym rynku pracy. Program ewentualnych działań nie jest łatwy do zaplanowania $z$ uwagi na duże zróżnicowanie odsetka NEET w ramach UE oraz inne wzory kształtowania się tej kategorii młodzieży w poszczególnych państwach członkowskich. Strategia dla najmłodszych obywateli naszego państwa, przynajmniej do 18 roku życia wydaje się oczywista - przeciwdziałanie przedwczesnemu odpływowi z edukacji lub reintegracja ze sferą edukacji po jej przedwczesnym opuszczeniu. W Polsce nadal zdarzają się jednostki, których rodzice lub opiekunowie dbają o wypełnianie obowiązku szkolnego, jednak ich odsetek na tle Unii Europejskiej jest stosunkowo niewielki.

Kolejną nasuwającą się wątpliwością jest to, czy współcześnie wystarczy uczyć się jedynie do uzyskania pełnoletności. Zgodnie z ideą lifelong learning 
każdy powinien nabywać nowe umiejętności, rozwijać się indywidualnie i społecznie, poszerzać wiedzę ogólną oraz podnosić kwalifikacje i kompetencje w okresie całego życia. W dzisiejszym szybko zmieniającym się świecie jest to ważne nie tylko wtedy, gdy jest się osobą bezrobotną czy zagrożoną utratą pracy, ale także odnoszącą sukcesy w swoim zawodzie, chcącą stanowisko pracy utrzymać lub zmienić, unikając stagnacji. Z drugiej strony trudno sobie wyobrazić, by jedynie kończenie kolejnych kursów do 29. roku życia bez podejmowania zatrudnienia miało zapewnić jednostce brak negatywnego zaetykietowania przynależnością do grupy NEET i być prostym sposobem na uniknięcie ekskluzji społecznej.

W zależności od specyfiki zjawiska w danym kraju i czynników ryzyka stawania się NEET-em, polityka państw wspólnotowych powinna wspomagać także płynne przejście z systemu edukacji na rynek pracy. Sterowane przepisami działania mogą się jednak okazać nieskuteczne bez wzmocnienia gospodarki i spadku bezrobocia, które umożliwi wchłonięcie na rynek młodych pracowników.

\section{BIBLIOGRAFIA}

Bazy danych Eurostat European Commission (stan na luty 2014): http://epp.eurostat.ec.europa.eu/ portal/page/portal/statistics/search_database.

Budnikowski T. (2009), Bezrobocie wyzwaniem współczesności, Instytut Zachodni, Poznań

Czapiński J., Panek T. (2013), Diagnoza społeczna. Warunki i jakość życia Polaków - Raport, Contemporary Economic, Warszawa.

Eurofound (2012a), NEETs - Young people not in employment, education or training: characteristics, costs and policy responses in Europe, Eurofound, Dublin.

Eurofound (2012b), Recent policy developments related to those not in employment, education and training (NEETS), Eurofound, Dublin.

European Commission (2012), EU Youth Report. Commission staff working document. Status of the situation of young people in the European Union, European Commission, Brussels.

Furlong A. (2007), The zone of precarity and discourses of vulnerability: NEET in the UK, ,Journal of Social Sciences and Humanities", no. 381.

Generation jobless (2013), „The Economist”, April 27 $7^{\text {th }}$.

Grotowska-Leder J. (2006), Rynek pracy młodych ludzi w Polsce. Szanse i zagrożenia w doradztwie zawodowym i pracy socjalnej, [w:] P. Szukalski (red.), Szansa na sukces. Recepty współczesnych Polaków, Łódzkie Towarzystwo Naukowe, Łódź.

Ratajczak Z. (2002), Utrata pracy - kryzys czy wyzwanie. Psychologiczne mechanizmy zaradności, „Kolokwia Psychologiczne”, nr 10

Serafin-Juszczak B. (2014), NEET - nowa kategoria młodzieży zagrożonej wykluczeniem społecznym, Acta Universitatis Lodziensis", Folia Sociologica 49 (przyjęty do druku).

Ustawa z dnia 7 września 1991 r. o systemie oświaty, Dz. U. z 2004, nr 256, poz. 2572, z późn. zm.

Warzywoda-Kruszyńska W. (red.) (2012), Bieda dzieci. Zaniedbanie, wykluczenie społeczne, Wydawnictwo UŁ, Łódź. 


\section{Polish NEET - Who is it?}

\section{Summary}

The phenomenon of NEET (not in employment, education or training), which was developed in the European Union, has not been comprehensively investigated in Poland. This problem concerns the situation of young people outside the employment sphere and the sphere of education, which makes them particularly vulnerable to social exclusion.

Different rates of young people in the labour market, particularly the unemployment rate, according to the European Union proved to be insufficient. In most countries the scale of NEET is not marginal and there are always variations within a given country. But there are also some additional difficulties in NEET analysis such as different legal conditions between Polish and other EU countries concerning the compulsory education or other forms of obligatory learning and heterogeneity of the age categories.

This article concerns the initial characteristics of the NEET category in Poland in comparison to the European Union.

Keywords: NEET, social exclusion, labour market, young people in Poland. 